\title{
Layanan Telemedis di Indonesia: Keniscayaan, Risiko, dan Batasan Etika
}

\author{
Pukovisa Prawiroharjo ${ }^{\mathrm{1}, 2}$, Peter Pratama, Nurfanida Librianty ${ }^{\mathrm{1}, 3}$ \\ ${ }^{1}$ Majelis Kehormatan Etik Kedokteran Pengurus Besar Ikatan Dokter Indonesia \\ ${ }^{2}$ Departemen Neurologi, Fakultas Kedokteran Universitas Indonesia/Rumah Sakit Cipto Mangunkusumo, Jakarta \\ ${ }^{3}$ Fakultas Kedokteran Universitas Pembangunan Nasional Veteran Jakarta
}

\author{
Kata Kunci \\ dokter, etika, kedokteran jarak jauh, \\ telemedis \\ Korespondensi \\ pukovisa@ui.ac.id \\ Publikasi \\ (C) 2019 JEKI/ilmiah.id \\ DOI \\ Io.26880/jeki.v3ir.27 \\ Tanggal masuk: 5 Oktober 2018 \\ Tanggal ditelaah: 12 Januari 2019 \\ Tanggal diterima: 16 Januari 2019 \\ Tanggal publikasi: 26 Februari 2019
}

\begin{abstract}
Abstrak Layanan telemedis memberikan kesempatan kepada dokter dan pasien untuk saling berinteraksi dari jarak jauh. Layanan telemedis antara dokter dan dokter telah lama berkembang dalam bentuk konsul, dan saat ini telesurgery dan teleradiologi merupakan fitur yang potensial untuk dikembangkan. Sementara itu layanan telemedis dokter-pasien makin berkembang bersama dunia internet, dan harus memperhatikan keterbatasan keyakinan profesional dokter terhadap kondisi klinis pasien, harapan dokter dan pasien dari layanan telemedis, dan aspek konfidensialitas informasi. Layanan telemedis memberikan kesempatan untuk menyelenggarakan praktik kedokteran yang terbebas dari batasan jarak, namun hendaknya tidak diarahkan untuk menggantikan interaksi tatap muka dokter-pasien. Layanan telemedis sebagai bagian dari kemajuan teknologi memang bersifat disruptif, oleh karena itu diperlukan regulasi untuk memastikan perkembangan layanan telemedis sesuai dengan tujuan dan nilai-nilai luhur etika kedokteran berdasarkan Kode Etik Kedokteran dan Sumpah Dokter. Pemerintah, Ikatan Dokter Indonesia, dan Majelis Kehormatan Etik Kedokteran diharapkan dapat mendukung dan mengawal perkembangan layanan telemedis ini ke arah yang baik dan saling bekerja sama dalam audit dan evaluasi layanan-layanan telemedis di Indonesia.
\end{abstract}

\begin{abstract}
Telemedicine provides opportunities for doctors and patients to interact remotely. Telemedicine between doctors and doctors has long developed in the form of consultations, and nowadays telesurgery and teleradiology are on promising development. Meanwhile doctor-patient telemedicine is growing together with the internet, yet must consider the limitations of physicians professional beliefs on patients' clinical conditions, doctors and patients' expectations from telemedicine, and aspects of information privacy. Telemedicine provides opportunities to conduct distance-free medical practices, but should never replace doctor'patient face-to-face interactions. Telemedicine as part of technological advance is indeed disruptive, therefore regulations are needed to ensure the development of telemedicine in accordance with the aims and noble values of medical ethics based on the Medical Ethics Code (KODEKI) and the Physician's Pledge. The government, the Indonesian Medical Association, and the Medical Ethics Council of Honor should support and oversee the development of telemedicine, and cooperate in auditing and evaluating all telemedical services in Indonesia.
\end{abstract}

Telemedis, berasal dari kata "tele-" yang berarti "jarak jauh", dan "medis" yang berarti "bersifat kedokteran". Secara keseluruhan, layanan telemedis berarti "layanan yang menggunakan fasilitas komunikasi elektronik untuk memberikan pelayanan atau dukungan medis dari jarak yang terpisah (tidak bertatap muka)". ${ }^{1}$ Fasilitas komunikasi yang digunakan bermacam-macam, dapat berupa telepon, panggilan video (video call), situs internet, atau alat canggih lainnya. Perlu diperhatikan bahwa layanan telemedis berbeda namun sangat 
berkaitan dengan cybermedicine, yang merupakan istilah untuk penggunaan teknologi internet dalam menyebarkan informasi klinis dan nonklinis kepada masyarakat umum. ${ }^{2,3}$

\section{Layanan Telemedis, Layanan yang Semestinya Menjadi Keniscayaan di Indonesia}

Kelebihan utama layanan telemedis adalah penggunaan teknologi untuk mengeliminasi batasan jarak dan geografis serta biaya yang terkait, khususnya untuk pelayanan medis di daerah terpencil yang kekurangan tenaga medis. ${ }^{1}$ Hal ini sangat relevan dan menjadi keniscayaan di Indonesia, yang memiliki area sangat luas, terdiri dari ribuan pulau, dengan infrastruktur transportasi penghubung masih belum baik, serta memiliki jumlah dokter yang sangat terbatas. Sementara itu, jaringan internet dapat ditunjang melalui satelit ke seluruh pelosok nusantara, melintasi kendala geografis seperti laut, bukit, gunung, hutan, dan sebagainya. Tentu saja dengan demikian pemerintah Indonesia perlu memprioritaskan investasi dalam pengadaan satelit milik negara yang dapat menunjang pelayanan telemedis.

Layanan telemedis dapat dikembangkan mulai dari edukasi, komunikasi/konsultasi, layanan farmasi jarak jauh, supervisi, ekspertisi, hingga pembedahan jarak jauh (telesurgery). Telesurgery menggunakan teknologi robotik dan komunikasi audiovisual sehingga seorang dokter dapat melakukan pembedahan dari jarak jauh, mengeliminasi batasan jarak dan geografis serta memudahkan operasi di tempat-tempat terpencil yang tidak memiliki tenaga ahli. ${ }^{4}$

Walau demikian, telesurgery masih menemui masalah bahkan dengan teknologi terbaik zaman kini akibat adanya jeda waktu antara masukan dan keluaran. Jeda waktu ideal untuk telesurgery adalah di bawah 100-200 milidetik; operasi akan mulai mengalami kesulitan bila jeda mencapai 300 milidetik, dan hampir tidak mungkin dilakukan bila mencapai 800 milidetik. ${ }^{4,5}$ Apalagi, untuk mempertahankan jeda waktu di bawah 100 milidetik ini, teknologi terbaik pun masih memerlukan kehadiran hingga 40 teknisi ahli. ${ }^{4}$ Dengan keterbatasan teknologi dan sumber daya yang ada di Indonesia, telesurgery nampaknya belum realistis untuk dapat diwujudkan.

Berdasarkan maksud diselenggarakannya, layanan telemedis dapat digolongkan menjadi untuk komunikasi/konsultasi dan supervisi antara staf medis, untuk ekspertise, dan untuk konsultasi antara dokter dan pasien. ${ }^{1}$

\section{Layanan Telemedis dengan Maksud Komunikasi/Konsultasi dan Supervisi antara Staf Medis}

Dalam layanan telemedis jenis ini, satu pihak staf medis melakukan interaksi tatap muka langsung dengan pasien, namun melibatkan staf medis lain yang dihubungi melalui layanan telemedis. Umumnya kedua pihak staf medis itu adalah sama-sama dokter atau tim dokter, namun dapat juga antara perawat home care dengan dokter. Dalam artikel ini pembahasan akan dibatasi pada komunikasi telemedis antara dokter dan dokter.

Contoh paling sederhana adalah konsul dokter jaga IGD kepada spesialis, atau konsul dokter residen kepada konsultannya. Semangat untuk konsultasi kepada dokter yang lebih ahli ini sangat sesuai dengan yang tertera pada Kode Etik Kedokteran (KODEKI) pasal 14, yang berbunyi "Seorang dokter wajib bersikap tulus ikhlas dan mempergunakan seluruh keilmuan dan ketrampilannya untuk kepentingan pasien, yang ketika ia tidak mampu melakukan suatu pemeriksaan atau pengobatan, atas persetujuan pasien/ keluarganya, ia wajib merujuk pasien kepada dokter yang mempunyai keahlian untuk itu." ${ }^{6}$ Dengan melibatkan dokter lain yang lebih kompeten melalui wahana telemedis, maka diharapkan dokter tersebut dapat memberikan pelayanan medis yang lebih berkualitas kepada pasiennya.

Dengan kemajuan teknologi di mana transmisi tidak lagi hanya audio tetapi juga visual melalui video, maka layanan telemedis dapat meningkat tidak hanya konsultasi tetapi juga supervisi. Misalnya seorang dokter umum yang menghubungi dokter spesialis saraf melalui layanan telemedis berupa video, kemudian diminta melakukan pemeriksaan refleks pupil. Spesialis neurologi tersebut kemudian dapat bersama-sama menilai refleks pupil pasien serta melakukan supervisi terhadap teknik 
pemeriksaan fisik yang dilakukan oleh dokter umum tersebut.

Layanan telemedis jenis ini umumnya tidak memiliki masalah etis selama diatur secara jelas peranan dan tanggung jawab masingmasing pihak, pengaturan tarif/renumerasi, serta kejelasan informasi yang diberikan kepada pasien. Pada umumnya, dokter yang bertatap muka tersebut tetap bertanggung jawab atas pelayanan yang sedang terjadi dan menjadi dokter penanggung jawab pasien setidaknya pada saat itu. Jika diperlukan pengalihan tanggung jawab kepada dokter yang dikonsulkan, hal ini dapat diatur baik melalui peraturan instansi/ RS atau kesepakatan antara kedua dokter. Pengaturan tarif/renumerasi masing-masing pihak dapat diatur oleh peraturan instansi/ RS atau menggunakan jasa penyedia layanan telemedis dengan mengedepankan asas keadilan dan proporsional. Informed consent juga perlu diperhatikan karena melibatkan pihak ketiga di luar interaksi klasik dokter-pasien, terutama jika dokter yang dikonsulkan bukan merupakan staf dari instansi yang sama karena umumnya di luar klausul general consent yang biasa dilakukan.

Catatan lainnya untuk layanan telemedis jenisiniadalah, hendaknya tidak disalahgunakan dengan pemberian delegasi yang tidak bertanggung jawab, ketika dokter yang bertatap muka sebenarnya bermaksud mengalihkan perawatan kepada yang dikonsulkan karena pasien memerlukan tindakan yang di luar kompetensinya, namun malah diminta melakukan tindakan tersebut oleh dokter yang dikonsulkan. ${ }^{7}$ Hal ini dapat dikecualikan ketika pasien secara praktis tidak mungkin dirujuk ke lokasi dokter dengan kompetensi terkait, misalnya karena di daerah terpencil atau kondisi pasien tidak memungkinkan untuk transportasi.

\section{Layanan Telemedis dengan Maksud Ekspertise}

Seperti halnya konsultasi antara dokter dengan spesialis, layanan telemedis dapat digunakan untuk memperoleh ekspertise atas pemeriksaan penunjang tertentu dari ahli atau spesialis terkait. Salah satu yang paling sering digunakan adalah teleradiologi, yakni penggunaan teknologi untuk mengirim data radiologis ke sentra lain untuk diinterpretasi oleh dokter spesialis radiologi di tempat tersebut. Teknik ini sangat membantu pelayanan medis mengingat jumlah spesialis radiologi yang sangat terbatas. ${ }^{1}$ Contohnya adalah Teleradiology Solutions, sebuah klinik asal India yang menerima pekerjaan teleradiologi dari Amerika Serikat, akibat kurangnya radiologis Amerika yang aktif di malam hari (yang berarti siang hari di India). Bukan hanya praktis secara zona waktu, klinik ini juga menawarkan biaya jasa yang lebih murah 35\% dibandingkan dengan radiologis asal Amerika. Tentunya, setiap dokter yang menerima teleradiologi tersebut harus terkualifikasi dan tersertifikasi di Amerika Serikat. $^{8}$

\section{Layanan Telemedis dengan Maksud Konsultasi antara Dokter dan Pasien}

Dalam layanan telemedis jenis ini, terjadi interaksi jarak jauh antara dokter dan pasien. Salah satu contoh klasik adalah layanan emergensi seperti layanan 911 di Amerika Serikat, di mana setiap orang dengan akses telepon dapat menghubungi nomor 911 ketika ada kegawatdaruratan termasuk dalam bidang medis. ${ }^{9}$ Layanan telemedis berpotensi untuk memberikan pelayanan triage medis yang cepat, mudah, dan murah, yang dapat mengarahkan pasien gawat darurat ke rumah sakit terdekat, memanggilkan ambulans, atau sekadar merujuk pasien ke spesialis yang tepat berdasarkan gejalanya.

Contoh klasik lainnya adalah layanan penanggulangan depresi yang bermaksud mencegah bunuh diri, yang juga ada di Amerika Serikat dan beberapa negara maju namun belum ada di Indonesia. ${ }^{10}$

Di era modern ini, semakin bermunculan program tertentu yang menawarkan konsultasi masalah kesehatan melalui internet atau aplikasi ponsel. Jenis inilah yang banyak berkembang di dunia termasuk Indonesia.

Walaupun dimulai dengan tujuan dan maksud yang baik, namun layanan telemedis jenis ini rentan dengan masalah etik, antara lain keyakinan profesional dokter terhadap informasi kondisi pasien yang didapatkan terbatas, perbedaan harapan dokter dan pasien, 
dan masalah konfidensialitas.

\section{Keyakinan Profesional Dokter terhadap Kondisi Klinis Pasien yang Didapatkan Terbatas}

KODEKI pasal 7 menjelaskan bahwa, "Seorang dokter wajib hanya memberi surat keterangan dan pendapat yang telah diperiksa sendiri kebenarannya". Pada cakupan pasal 7 tersebut juga disebutkan pada ayat 1, "Dalam memberikan surat keterangan medis/ahli atau ekspertis dan pendapat ahli apapun bentuk dan tujuannya, dokter wajib mendasarkan isinya pada fakta medis yang diyakininya benar sesuai dengan pertanggungjawaban profesinya sebagai dokter". Salah satu frase kunci pada uraian pasal di atas ialah bahwa dokter dalam memberi pendapat harus berdasarkan kondisi klinis pasien yang "diyakininya benar". Perlu ada keyakinan profesional dari dokter dalam setiap putusan profesional yang dibuat, termasuk di dalamnya penegakan diagnosis dan penentuan tatalaksana. ${ }^{6}$

Dokter perlu menyadari bahwa wahana telemedis memiliki keterbatasan dalam menyajikan keutuhan informasi kondisi klinis pasien. Dokter harus mempertimbangkan apakah informasi kondisi klinis pasien yang tersaji tidak utuh tersebut cukup untuk melahirkan keyakinan profesional secara adekuat sehingga kemudian dapat ditindaklanjuti menjadi penegakan diagnosis dan penentuan tatalaksana kepada pasien.

Sesungguhnya seorang dokter dapat saja menegakkan 2 dari 3 diagnosis hanya berdasarkan kemampuan anamnesis yang baik, namun pemeriksaan fisik akan memberikan $20 \%$ informasi tambahan yang mungkin signifikan dan bahkan mengubah arah diagnosis. ${ }^{11}$ Pemeriksaan fisik yang sifatnya observasional (inspeksi) memang dapat difasilitasi melalui layanan telemedis dengan metode video, namun pemeriksaan fisik lainnya yang non-observasional (palpasi, perkusi, dan auskultasi) atau memerlukan manuver khusus tidak mungkin didapatkan melalui wahana telemedis. Contoh kasus yang bisa mendapatkan keuntungan dari layanan telemedis dengan metode video dan pengambilan gambar ialah kasus-kasus dermatologi, karena sebagian diagnosisnya dapat ditegakkan melalui inspeksi. Namun ada beberapa hal yang tetap harus diperhatikan seperti pengaruh pencahayaan dan kontras dalam pengambilan gambar, serta kontur tiga dimensi yang sulit diperoleh dari layanan telemedis semata tanpa manuver atau pemeriksaan langsung.

Keterbatasan informasi tersebut berpotensi menyebabkan pelayanan medis menjadi serba terbatas atau bahkan salah mengambil keputusan. Semua dokter yang dikonsultasikan secara telemedis perlu mempertimbangkan untuk mendorong pasien memeriksakan diri ke dokter umum/spesialis terdekat, atau mengirimkan dokter ke rumah pasien untuk kunjungan rumah (home visit). Di sisi lain, hal ini wajib menjadi pertimbangan aplikasi yang menyediakan wahana telemedis. Aplikasi tersebut perlu mempertimbangkan masakmasak terkait keterbatasan tersebut jika ingin mengintegrasikan layanan telemedis ini dengan layanan farmasi/apotek jarak jauh, mulai dari peresepan dari dokter, pembelian, hingga pengiriman obat kepada pasien.

Salah satu masalah yang terjadi akibat keterbatasan informasi dan kepercayaan profesional ini adalah kasus yang terjadi di California pada tahun 2007. Seorang dokter telemedis di Colorado mendapat konsultasi melalui formulir daring dari pasien di California mengenai depresi yang dideritanya. Dokter tersebut meresepkan fluoksetin, salah satu antidepresan yang umum digunakan. Beberapa minggu setelahnya, pasien tersebut ditemukan meninggal bunuh diri dengan karbon monoksida. Di dalam darahnya ditemukan alkohol dan fluoksetin. Walaupun hal ini mungkin saja terjadi dalam layanan medis tatap muka klasik, namun risiko tersebut tentunya dapat diminimalisir melalui evaluasi psikiatrik yang komprehensif dan holistik. Mungkin saja pasien tersebut sudah berisiko tinggi bunuh diri saat konsultasi, dan hal ini dapat ditemukan bila interaksi tersebut adalah tatap muka langsung, sehingga dokter tersebut dapat memberikan kombinasi obat psikiatrik, psikoterapi, anjuran rawat inap, dan sebagainya. Dokter dalam kasus tersebut dijatuhi hukuman akibat memberikan 
obat berbahaya tanpa pemeriksaan adekuat terlebih dahulu. ${ }^{12}$

Dalam konteks layanan konsultasi telemedis digunakan oleh pasien atau keluarganya untuk kepentingan menggali opini kedua/pembanding pada situasi pasien sedang dalam perawatan di suatu RS, maka dokter yang dihubungi melalui wahana telemedis tersebut harus mempertimbangkan bahwa modalitas informasi yang didapatkan dirinya sejatinya asimetris (tidak seimbang) dibandingkan keutuhan informasi yang didapatkan sejawat yang sedang merawatnya. Secara umum, dokter yang dihubungi melalui wahana telemedis pada konteks ini perlu mengarahkan pasien dan atau keluarganya untuk menanyakan hal-hal tersebut ke dokter atau tim dokter yang sedang merawatnya.

Dokter telemedis juga perlu mengingat bahwa mungkin saja pasien atau keluarga yang mengkonsulkannya merahasiakan bahwa ia sebenarnya dalam perawatan (seperti kasus di atas) dengan maksud membandingkan opini sang dokter telemedis dengan dokter yang merawat. Oleh karena itu, dokter telemedis perlu sangat berhati-hati dan mengingat asimetrisme informasi yang dimilikinya, serta menjauhkan diri dari perkataan dan pendapat yang mendiskreditkan sejawatnya.

Dalam konteks dokter telemedis menangkap bahwa kondisi klinis pasien yang dikonsulkan kepadanya mengarah ke penyakit yang memerlukan pertolongan gawat darurat, maka penyelamatan nyawa/ kecacatan pada konteks kegawatdaruratan perlu diutamakan bahkan diunggulkan secara prioritas dibandingkan aturan-aturan yang ada. Dokter dapat memanfaatkan wahana telemedis ini sebaik-baiknya untuk memberi saran terbaik mengenai pertolongan pertama kegawatdaruratan sambil menganjurkan agar pasien segera dibawa ke RS terdekat.

\section{Perbedaan Harapan Dokter-Pasien}

Layanan-layanan telemedis yang bereputasi baik dibuat dengan sistem yang didesain dengan memperhatikan keterbatasan seperti yang dimaksud di atas. Umumnya pelayanan ini memberikan saran medis semata dan tidak bertujuan menggantikan interaksi dokter-pasien yang sesungguhnya. Hal ini kiranya perlu jelas ditekankan dalam tiap pemberian saran, dan tidak semata tertimbun di balik persetujuan pengguna yang terdiri atas puluhan paragraf.

Sayangnya, kadang ada yang kurang memahami tujuan mulia dari layanan-layanan demikian. Misalnya dokter yang menganggap bahwa layanan telemedis merupakan ruang praktik pribadinya, memberikan saran tatalaksana seolah telah memeriksa sendiri pasien tersebut, misalnya menganjurkan konsumsi antibiotik atau obat-obatan berisiko tinggi. Padahal informasi yang dimilikinya sangat terbatas. Hal ini harus selalu diingat dan dicegah oleh pihak penyelenggara melalui edukasi rutin kepada dokter-dokter stafnya.

Dokter yang berkiprah dalam dunia telemedis harus sangat berhati-hati dalam memberikan saran medisnya sebagaimana dalam praktik dunia nyata. Jangan sampai saran ini bersifat keliru (hoax), mengiklankan produk tertentu, atau bahkan mengiklankan dirinya sendiri secara berlebihan. ${ }^{13}$ Dokter tersebut juga harus memperhatikan kemungkinan bahwa sarannya tersebut digunakan pembaca untuk mendiagnosis dirinya sendiri, atau bahkan dijadikan "senjata" bagi pasien tertentu untuk menyerang sejawat lainnya seperti halnya dalam cybermedicine. ${ }^{3}$

\section{Konfidensialitas dan Kerahasiaan Informasi}

Dokter bertanggung jawab untuk memberikan pelayanan medis yang maksimal bagi pasiennya, dan untuk itu ia berhak dan bertanggung jawab memperoleh semua informasi yang menunjang tanggung jawabnya itu. Pelayanan kedokteran tidak akan maksimal bila ada informasi berkaitan yang tidak ditanyakan dokter, atau sebaliknya dirahasiakan oleh sang pasien. KODEKI pasal 16 menjelaskan bahwa, "Setiap dokter wajib merahasiakan segala sesuatu yang diketahuinya tentang seorang pasien, bahkan juga setelah pasien itu meninggal dunia." ${ }^{6}$ Dalam setting dokter tatap muka dengan pasien, hanya ada 4 pihak yang mungkin mengetahui informasi yang mungkin bersifat sangat rahasia 
itu: dokter, perawat dan staf medis, pasien sendiri, dan pendamping pasien (yang disetujui pasien untuk ikut mendengarkan). Selain itu, informasi tersebut juga mungkin tertulis dalam rekam medis. Namun dalam setting telemedis, ada beberapa pihak lain yang dapat mengetahui informasi tersebut tanpa sepengetahuan dokter dan pasien, misalnya penyedia layanan internet, penyedia layanan server perantara, staf lain dari layanan telemedis (termasuk dokter dan teknisi), para peretas (hacker), dan bahkan orang-orang lain yang memiliki akses ke instrumen (misalnya komputer, laptop, atau ponsel) yang digunakan pasien untuk layanan telemedis.

Tiap penyedia layanan internet dan penyedia layanan server umumnya berjanji akan menjaga kerahasiaan dan tidak akan menyadap data yang digunakan kliennya. Apalagi, mengingat data yang mereka layani berukuran sangat besar, mungkin mencapai jutaan gigabyte per detik, agaknya mustahil mereka mampu menyadap data yang spesifik pasien secara kebetulan, belum lagi penjagaan melalui metode enkripsi yang digunakan penyelenggara layanan telemedis. Selain itu, hal ini mudah dicegah dengan menggunakan penyedia layanan internet dan penyedia layanan server yang telah dikenal memiliki reputasi yang baik; mereka akan berusaha sepenuhnya untuk menjaga kerahasiaan ini karena pelanggaran dapat berakibat tuntutan hukum dan hilangnya kepercayaan publik.

Demikian pula tiap layanan telemedis umumnya memiliki protokol dan persetujuan konfidensialitas yang menjanjikan keamanan dan kerahasiaan data khususnya dari penyalahgunaan internal. Beberapa layanan telemedik mempublikasikan jawaban atas pertanyaankesehatanumumdisitusnya; tentunya mereka harus sangat berhati-hati memilah mana jawaban yang boleh dipublikasikan dan mana yang tidak, serta harus selalu menyembunyikan identitas pasien termasuk inisial namanya (identitas minimal seperti jenis kelamin dan usia masih diperbolehkan). Masalah lain yang mungkin muncul dapat dicegah dengan hanya menggunakan situs-situs yang memiliki reputasi baik.

Namun, masalah peretas dan orang-orang yang memiliki akses ke instrumen telemedis tanpa persetujuan (misalnya, teman atau kekasih yang mengetahui kata kunci pelayanan) adalah di luar kemampuan dan tanggung jawab pihak penyelenggara. Pasien harus selalu diingatkan bahwa datanya dapat bocor dari sisi klien. Hal-hal yang dapat dilakukan pasien untuk mencegah hal ini antara lain dengan pembaharuan sistem berkala, memasang program antivirus dan firewall yang terpercaya, merahasiakan kata kunci pelayanan, dan sebagainya.

Kemungkinan masalah konfidensialitas lain adalah seperti pada layanan telemedis antara dokter dan dokter, yakni orang asing yang mencuri dengar percakapan telepon telemedis atau kebetulan mencuri lihat dari belakang pasien saat berkonsultasi melalui fitur chatting/forum. Perbedaannya, staf dan dokter telemedis adalah tenaga berpengalaman yang telah diwanti-wanti mengenai konfidensialitas pasien, bahkan bagi dokter tercantum dalam KODEKI, sementara pasien adalah orang awam yang mungkin kurang memperhatikan hal ini. Selain itu, orang-orang yang tidak bertanggung jawab tersebut akan segera tahu siapa pasien yang dimaksud dalam konsultasi tersebut, yakni tentunya orang yang mereka curi lihat/ dengar. Pasien harus selalu berusaha mencegah kemungkinan tersebut, misalnya dengan hanya berkonsultasi di tempat tertutup dan pribadi.

\section{Risiko Layanan Telemedis}

Layanan telemedis mengundang berbagai topik yang berpotensi menjadi masalah etik, yang relevan dengan pelaksanaannya di Indonesia antara lain masalah privasi dan konfidensialitas pasien, serta berubahnya interaksi tatap muka dokter-pasien., ${ }^{1,14-16}$

Peretasan keamanan konfidensialitas data pasien termasuk data teks, audio, dan visual/video adalah salah satu risiko utama sistem telemedis. Hal ini sangat perlu untuk diperhatikan, lebih-lebih bila ada data-data sensitif pasien yang akan sangat merugikan jika terpublikasi, seperti riwayat penyakit menular seksual dan gangguan jiwa. Hendaknya keamanan data yang bersifat konfidensial ini dijaga semaksimal mungkin, misalnya dengan memastikan dokter yang dikonsulkan berada di 
tempat yang dapat menjaga kerahasiaan (seperti dalam ruangan pribadi) bila menggunakan telepon, untuk mencegah orang yang mencuri dengar. Atau bila dilakukan dengan aplikasi chatting melalui ponsel pintar, hendaknya menggunakan aplikasi yang bereputasi baik dalam hal konfidensialitas dan mencegah orang yang mencuri lihat.

Data di Amerika Serikat mencatat 1.138 kasus penerobosan data dalam tahun 20092017 yang melibatkan 164 juta pasien, dengan rincian 22,2 juta pasien merupakan akibat kasus pencurian perangkat, 20,3 juta pasien akibat akses ilegal, 133,8 juta pasien akibat peretasan, 5,7 juta pasien akibat data hilang, dan 700 ribu pasien akibat pembuangan data yang tidak tepat. Padahal, Amerika Serikat mempunyai Health Insurance Portability and Accountability Act (HIPAA) yang dicetuskan oleh Departemen Kesehatan dan Layanan Masyarakat Amerika Serikat untuk meregulasi keamanan data kesehatan rakyatnya. ${ }^{17}$

Sementara itu, layanan telemedis juga menyebabkan perubahan interaksi tatap muka klasik dokter dan pasien. Secara positif, interaksi ini berarti pasien dapat menjangkau dokternya dengan lebih mudah, cepat, murah, dan sering. Pasien dapat terus mengkonsultasikan keadaan kesehataannya dengan dokter. Secara negatif, keyakinan profesional dokter terhadap kondisi klinis pasien sangat terbatas seperti yang diuraikan di atas.

Perubahan interaksi ini juga menyebabkan ketidakjelasan bila muncul kasus malpraktik, karena layanan telemedis tidak didata oleh Ikatan Dokter Indonesia (IDI) maupun pemerintah, demikian juga dokter-dokternya yang tidak memiliki SIP untuk pelayanan tersebut.

\section{Peran Ikatan Dokter Indonesia (IDI) dan Majelis Kehormatan Etik Kedokteran (MKEK) dalam Layanan Telemedis}

Pada dasarnya KODEKI dan peraturanperaturan yang belaku dapat menjadi inspirasi untuk mengarahkan perkembangan layanan telemedis sebagai wahana penghubung antardokter maupun dokter dengan pasien. IDI dan MKEK hendaknya dapat mengarahkan perkembangan layanan telemedis untuk dapat dirasakan manfaatnya secara luas, namun tanpa melupakan nilai-nilai luhur profesi kedokteran. Layanan telemedis hendaknya dikembangkan bukan untuk merusak, melainkan memperkuat nilai-nilai luhur etika kedokteran berdasarkan KODEKI dan Sumpah Dokter.

Dengan demikian, IDI dan MKEK perlu mulai memperhatikan layanan-layanan telemedis yang makin menjamur, karena sesungguhnya praktik-praktik ini memberikan saran medis layaknya praktik dokter biasa, dan hingga saat ini belum dikendalikan peraturan apapun; dokter telemedis tidak memerlukan SIP, dan layanannya pun tidak memerlukan izin. Argumen bahwa dokter telemedis tidak perlu regulasi karena tidak memberikan obat tidaklah sepenuhnya tepat, karena tata laksana non-medikamentosa, termasuk saran-saran medis yang diberikan, masih termasuk domain kedokteran. Bahkan sesungguhnya praktik kedokteran sudah dimulai sejak dilakukannya anamnesis, di mana pasien membuka informasi tentang dirinya dan kondisi medisnya kepada dokter.

IDI/MKEK bekerja sama dengan pemerintah perlu mendata dan mengaudit semua layanan semacam ini, baik dari segi protokol pelayanan maupun teknis internet, demi menjamin kualitas pelayanan kesehatan dan konfidensialitas pasien. Kemudian IDI/ MKEK dapat memberikan saran perbaikan untuk pelayanan yang terbukti kurang atau bahkan mengadvokasi penutupan layanan yang bandel. Dokter dan pelayanan telemedis perlu didaftarkan secara terpusat, misalnya dengan pemberian izin praktik telemedis khusus yang diatur dalam regulasi negara. MKEK juga perlu menerbitkan fatwa etik yang sesuai sebagai batasan etik umum bagi dokter-dokter yang menjalankan layanan telemedis. IDI dan MKEK hendaknya tegas kepada pelayanan-pelayanan telemedis yang ditemukan mulai menyimpang, dan memastikan agar interaksi jarak jauh ini tidak menggeser keluhuran interaksi dokterpasien.

\section{Peran Pemerintah Dalam Layanan Telemedis}

Sistem telemedis sesungguhnya berpotensi 
besar bagi pemerintah Republik Indonesia dalam menjangkau kesehatan rakyatnya yang berjumlah sangat besar. Misalnya adalah dengan penggunaan layanan telemedis oleh dokter keluarga atau Puskesmas untuk memonitor kesehatan masyarakat setempat dan memberikan edukasi kesehatan.

Sistem telemedis yang dikembangkan dengan baik akan mengatasi ketimpangan jumlah dokter di kota besar dan daerah terpencil, khususnya spesialis-spesialis tertentu. Layanan telemedis ini dapat berupa komunikasi telemedis dokter-dokter maupun dokter-pasien. Sayangnya hingga kini, layanan telemedis dokter-pasien yang berkembang di Indonesia adalah berupa layanan forum atau chatting dan berbasis forum atau aplikasi ponsel, sehingga menyulitkan masyarakat di daerah terpencil yang belum atau kurang terjangkau internet dan tidak memiliki ponsel pintar yang mampu mengoperasikan aplikasi-aplikasi tersebut. Akibatnya, layanan telemedis yang awalnya dimaksudkan untuk mengatasi batasan jarak dan geografis justru dibatasi lagi oleh jarak.

Alternatifnya adalah dengan membangun sistem telemedis berbasis pemerintah yang menggunakan media telepon, misalnya digabungkan dengan layanan darurat lainnya menyerupai 911 di negara maju, karena jaringan telepon lebih menjangkau daerah terpencil dibandingkan internet. Alternatif lainnya dapat dirundingkan dengan IDI sebagai organisasi profesi kedokteran setelah melihat dan menilai fasilitas dan infrastruktur lokal.

\section{KESIMPULAN}

Layanan telemedis memberikan kesempatan untuk menyelenggarakan praktik kedokteran yang terbebas dari batasan jarak, namun hendaknya tidak diarahkan untuk menggantikan interaksi tatap muka dokterpasien. Layanan telemedis sebagai bagian dari kemajuan teknologi memang bersifat disruptif, oleh karena itu diperlukan regulasi untuk memastikan perkembangan layanan telemedis sesuai dengan tujuan dan nilai-nilai luhur etika kedokteran berdasarkan KODEKI dan Sumpah Dokter. Pemerintah, IDI, dan MKEK diharapkan dapat mendukung dan mengawal perkembangan layanan telemedis ini ke arah yang baik dan saling bekerja sama dalam audit dan evaluasi layanan-layanan telemedis di Indonesia.

\section{KONFLIK KEPENTINGAN}

Tidak ada konflik kepentingan; penulis tidak mempunyai konflik kepentingan terhadap bisnis telemedis yang ada di Indonesia.

\section{REFERENSI}

1. Institute of Medicine. Telemedicine: A guide to assessing telecommunications in healthcare. Field MJ, editor. Washington, D.C.: National Academies Press; 1996. 288 p.

2. Eysenbach G, Sa ER, Diepgen TL. Shopping around the internet today and tomorrow: Towards the millennium of cybermedicine. BMJ. 1999 Nov 13;319(7220):12941294. https://doi.org/10.1136/ bmj.319.7220.1294.

3. Santosa F, Purwadianto A, Sidipratomo P, Pratama P, Prawiroharjo P. Sikap etis dokter terhadap pasien yang "mendiagnosis" diri sendiri menggunakan informasi Internet pada era cyber medicine. J Etik Ked Ind. 2018 Jun 12;2(2):53. https://doi.org/10.26880/ jeki.v2i2.16.

4. ChoiPJ, Oskouian RJ, Tubbs RS. Telesurgery: Past, present, and future. Cureus. 2018 May 31; https://doi.org/10.7759/cureus.2716.

5. Xu S, Perez M, Yang K, Perrenot C, Felblinger J, Hubert J. Determination of the latency effects on surgical performance and the acceptable latency levels in telesurgery using the dV-Trainer ${ }^{\circledR}$ simulator. Surg Endosc. 2014 Sep 27;28(9):2569-76. https://doi. org/10.1007/s00464-014-3504-z.

6. Majelis Kehormatan Etik Kedokteran Indonesia. Kode etik kedokteran tahun 2012. Jakarta; 2012. 
7. Prawiroharjo P, Mulyana RM, Sidipratomo P, Purwadianto A. Benarkah Dokter Spesialis yang Tugas Jaga Pasti Melakukan Pelanggaran Etik Jika Sekedar Menjawab Konsul per Telepon untuk Pertolongan Kegawatdaruratan? J Etik Ked Ind. 2018 Mar 19;2(1):31. https://doi.org/10.26880/ jeki.v2i1.13.

8. Chandran K. Teleradiology paves way for remote medicine [Internet]. 2008 [disitasi 2019 Jan 12]. Diunduh dari: https:// www.reuters.com/article/us-teleradiologyindia/teleradiology-paves-way-for-remotemedicine-idUSTRE49E01920081015

9. Federal Communications Commission. 911 and E911 services [Internet]. 2018 [disitasi 2019 Jan 11]. Diunduh dari: https://www. fcc.gov/general/9-1-1-and-e9-1-1-services

10. National Suicide Prevention Lifeline [Internet]. $2005 \quad$ [disitasi 2019 Jan 12]. Diunduh dari: https:// suicidepreventionlifeline.org/

11. Walker HK, Hall WD, Hurst JW, editors. Clinical methods: The history, physical, and laboratory examinations. 3rd ed. Boston: Butterworths; 1990.

12. Kline JA. Hageseth v. Superior Court, 150 Cal. App. 4th 1399 (Cal. Ct. App. 2007), California Court of Appeal. California; 2007.

13. Prawiroharjo P, Meilia PDI. Dokter beriklan: Sebuah tinjauan menurut Kode Etik Kedokteran Indonesia (KODEKI) tahun 2012. J Etik Ked Ind. 2017 Oct 11;1(1):13. https://doi.org/10.26880/jeki.v1i1.4.

14. Moghbeli F, Langarizadeh M, Ali A. Application of ethics for providing telemedicine services and information technology. Med Arch. 2017;71(5):351. https://doi.org/10.5455/ medarh.2017.71.351-355.

15. Kaplan B, Litewka S. Ethical challenges of telemedicine and telehealth. Cambridge $Q$ Healthc Ethics. 2008 Oct 26;17(04). https:// doi.org/10.1017/S0963180108080535.
16. Stanberry B. Legal and ethical aspects of telemedicine. J Telemed Telecare. 2006 Jun 24;12(4):166-75. https://doi. org/10.1258/135763306777488825.

17. Jiang J (Xuefeng), Bai G. Evaluation of causes of protected health information breaches. JAMA Intern Med. 2018 Nov 19; https://doi. org/10.1001/jamainternmed.2018.5295. 